Uniwersytet w Białymstoku

Wydział Filologiczny

Instytut Filologii Wschodniosłowiańskiej

tel. +48857457450

e-mail: ldacewicz@interia.pl

ORCID ID: https://orcid.org/0000-0001-5551-7208

\title{
Podlasie w badaniach onomastycznych w przekroju historycznym - stan obecny, zadania i potrzeby
}

Słowa kluczowe: Podlasie, badania onomastyczne, zakres chronologiczny, zakres tematyczny

Przeszłość Podlasia od dawna stanowi obiekt zainteresowań badaczy kilku dyscyplin naukowych, m.in. historyków i językoznawców. Celem niniejszego opracowania jest przegląd i charakterystyka dotychczasowych osiągnięć badaczy (głównie pracowników naukowych Wydziału Filologicznego Uniwersytetu w Białymstoku) zajmujących się badaniami onomastycznymi Polski północno-wschodniej. Określając zasięg terytorialny badań należy ograniczyć się do Podlasia (na przestrzeni wieków jego obszar i przynależność polityczno-administracyjna podlegały zmianom), bowiem odwoływanie się do nazwy Polska północno-wschodnia jest dość nieprecyzyjne. Po pierwsze, na tym dość dużym obszarze można wyodrębnić trzy regiony: Warmia, Mazury, Podlasie; po drugie, nazewnictwo osobowe i geograficzne w wymienionych regionach kształtowało się na bazie różnych systemów językowych.

\section{Różnorodność etniczna, wyznaniowa i językowa Podlasia}

Badania onomastyczne, dotyczące antroponimii i toponimii Podlasia, zarówno w ujęciu diachronicznym jak i synchronicznym, są dość trudne, po- 
nieważ wymagają analizy nazw należących do kilku różnych języków - języka polskiego, języków wschodniosłowiańskich (białoruskiego i ukraińskiego oraz ich gwar), języka litewskiego. W okresie historycznym (XV-XIX w.) pojawiło się nazewnictwo żydowskie, tatarskie, niemieckie w związku z osiedlaniem się dość licznych grup przedstawicieli tych narodowości, a więc ludności żydowskiej, różnego pochodzenia ludności określanej mianem Tatarów, od II połowy XVIII w. też Niemców (głównie w Białymstoku).

Specyficzna dla obszaru Podlasia różnorodność etniczna, wyznaniowa i językowa znalazła odzwierciedlenie w nazewnictwie tych ziem. Obok dominujących antroponimów i toponimów polskich występują nazwy wschodniosłowiańskie (głównie białoruskie i ukraińskie) i bałtyckie (głównie litewskie, pruskie), nazewnictwo żydowskie, tatarskie i niemieckie. Rezultatem różnorodnych procesów adaptacyjnych, związanych ze złożoną historią osadniczą i polityczną Podlasia, były wzajemne interferencje językowe. Znaczny procent nazw ma charakter hybrydalny, czyli łączący elementy językowe różnego pochodzenia, np. polsko-białoruskie, polsko-litewskie, polsko-tatarskie, białorusko-litewskie itd. Zróżnicowane pod względem etniczno-językowym nazewnictwo znalazło się w kręgu zainteresowań białostockich onomastów. Wschodniosłowiański substrat nazewniczy: białoruski głównie w części północnej, a ukraiński - w części południowej województwa podlaskiego, jest przedmiotem analizy w pracach wielu badaczy, bowiem osadnictwo ruskie na przestrzeni kilku wieków miało szeroki zasięg terytorialny oraz było znaczne liczebnie. Należy tu wymienić liczne prace takich autorów jak: Zofia Abramowicz, Elżbieta Bogdanowicz, Lilia Citko, Leonarda Dacewicz, Michał Kondratiuk, Krzysztof Rutkowski, Michał Mordań, Alina Filinowicz. Nazewnictwo żydowskie prezentują prace Leonardy Dacewicz (okres XVI-XVIII w.) i Zofii Abramowicz (XIX-XX w.); litewskie - Michała Kondratiuka i Lili Citko; tatarskie i niemieckie - L. Dacewicz.

\section{Zakres chronologiczny i terytorialny badań}

Zakres chronologiczny i terytorialny badań w znacznym stopniu był i jest uzależniony od zasobów i dostępności bazy źródłowej [zob. Dacewicz 2003, 91-98]. Wybór źródeł, ich ilość i dostępność stoi w ścisłym związku z historią terenu, do którego są przypisane. Losy pogranicznego terytorium, jakim było Podlasie, na przestrzeni wieków charakteryzowały się dużą zmiennością: wojny, przemarsze wojsk i związane z tym zniszczenia, zmiana przynależności państwowej. Zaginęło wiele ksiąg grodzkich i ziemskich województwa podlaskiego, wiele dokumentów znalazło się za grani- 
cą, w archiwach Grodna, Mińska, Moskwy i Wilna. Niemniej jednak spory ich zasób, w tym dokumentów rękopiśmiennych, zachował się w polskich archiwach, np. rejestry podatkowe (podymnego, pogłównego), inwentarze pomiary włócznej, inwentarze starostw i leśnictw, lustracje województwa podlaskiego, popisy wojsk litewskich, akta sądowe, opisy parafii i księgi metrykalne. Te ostatnie, niestety, datują się dopiero od XVIII w. i to głównie jego drugiej połowy. Biorąc pod uwagę wartość historycznych ksiąg metrykalnych dla badań historycznych, socjologicznych, demograficznych i językoznawczych, w tym onomastycznych, można mówić o trudnej do ocenienia stracie. Najwcześniejsze dokumenty, dotyczące Podlasia, datowane na XIV i XV w. nie są zasobne w antroponimy. Natomiast okres XVI-XIX w. jest dość dobrze udokumentowany. Zachowało się sporo dokumentów zawierających imienne rejestry osobowe i nazewnictwo toponimiczne. Dzięki staraniom historyków, przede wszystkim z Uniwersytetu w Białymstoku, źródła rękopiśmienne systematycznie ukazują się drukiem. Edycją źródeł zajęła się także autorka niniejszego artykułu. Do najnowszych, choć na razie dość skromnych, sukcesów na tym polu należy zaliczyć ukazanie się drukiem fragmentów ksiąg metrykalnych chrztów dekanatu białostockiego z 1875 r. - alfabetyczne imienne spisy urodzonych i ochrzczonych. Jest to początek serii i jednocześnie zdecydowany krok w badaniach antroponimii Podlasia XIX w. nie cieszącej się, jak dotąd, większym zainteresowaniem badaczy. Głównym powodem słabego zainteresowania badaniami antroponimii XIX-wiecznego Podlasia są trudności związane z ekscerpcją materiału nazewniczego z rękopiśmiennych źródeł prowadzonych w języku rosyjskim (okres zaboru rosyjskiego). Systematyczna edycja wybranych materiałów z ksiąg metrykalnych w pewnym stopniu powinna te badania ułatwić.

$\mathrm{W}$ badaniach onomastycznych głównie z zakresu antroponimii historycznej) prowadzonych na Wydziale Filologicznym Uniwersytetu w Białymstoku, uwzględniano poszczególne części dawnego województwa podlaskiego: część północną lub południową, poszczególne powiaty lub ziemie, np. bielski, drohicki, mielnicki, oddzielne miejscowości, np. Białystok, Brańsk, Mielnik, Łosice, Narew, Suraż, Tykocin itd., cały obszar Podlasia i częściowo Wielkiego Księstwa Litewskiego, ponieważ Podlasie okresowo stanowiło jego część składową. Świadczą o tym tytuły monografii, słowników i bardzo licznych artykułów, np. L. Citko, Nazewnictwo osobowe pótnocnego Podlasia w XVI w. (2001), E. Bogdanowicz, Antroponimia poludniowej Białostocczyzny w XVIII wieku (praca doktorska, Białystok 2000); A. Berlińska, Antroponimia Tykocina od XVI do XIX wieku (praca doktorska, Białystok 1988), Z. Abramowicz, Antroponimia Żydów białostockich (2010); L. Dacewicz, Nazewnictwo kobiet $w$ dawnym powiecie mielnickim (XVI-XVII wiek) 1994, 
Antroponimia Bialegostoku w XVII-XVIII wieku (2001), Antroponimia Żydów Podlasia w XVI-XVIII wieku (2008), Historia nazwisk polskich na kresach pótnocno-wschodnich Rzeczpospolitej w XVI-XVIII w. (2014).

\section{Założenia i cele badań}

W badaniach onomastyki Podlasia uwzględniano wiele aspektów, ponieważ nazewnictwo tego regionu było i jest ściśle związane z historią i kulturą tego regionu, stosunkami społeczno-gospodarczymi, a także różnymi zjawiskami socjologicznymi. Na podstawie dotychczas opublikowanych prac można stwierdzić, że ich Autorom przyświecały następujące założenia i cele:

- opis zasobów archiwalnych w kontekście historii osadnictwa tego regionu w przekroju historycznym;

- zgromadzenie zasobu imion i innych nazw osobowych pełniących funkcję nazwisk drogą ekscerpcji rękopiśmiennych i drukowanych źródeł z okresu XVI-XIX wieku;

- przedstawienie zasobu i frekwencji imion w formach podstawowych i hipokorystycznych, analiza sposobów tworzenia licznych form pochodnych należących do różnych systemów językowych: polskiego, wschodniosłowiańskiego, żydowskiego;

- klasyfikacja zgromadzonego zasobu nazwisk (we wcześniejszych stuleciach były to różnorodne antroponimy pełniące funkcję nazwisk, czyli tzw. nazwiska zwyczajowe) według kryteriów znaczeniowo-formalnych ze wskazaniem produktywności typów słowotwórczych;

- opis procesu kształtowania się nazwisk zwyczajowych w poszczególnych stuleciach i poszczególnych warstwach społecznych;

- uchwycenie typowych dla badanego okresu i terytorium oraz danej warstwy społecznej nazwisk i formuł identyfikacyjnych;

- wskazanie osobliwości (np. zjawisko hybrydyzacji) antroponimów na obszarze charakteryzującym się znacznym stopniem etnolingwistycznego zróżnicowania, łączenia tradycji nazewniczej Słowian wschodnich i zachodnich, tworzących trzon osadnictwa na Podlasiu, ale też wyraźnej obecności Litwinów, Żydów, Tatarów i Niemców;

- zjawisko rusyfikacji nazewnictwa polskiego (imion, nazwisk, zestawień antroponimicznych) w okresie zaboru rosyjskiego; repolonizacja nazwisk po odzyskaniu niepodległości.

Wymienione zagadnienia w węższym lub szerszym stopniu znalazły odzwierciedlenie w kilkunastu monografiach, kilku opracowaniach leksykograficznych i bardzo licznych artykułach, których autorami są głównie pracow- 
nicy Wydziału Filologicznego Uniwersytetu w Białymstoku. Ważny był też udział badaczy z Instytutu UMCS, m.in. Michała Sajewicza, Piotra Złotkowskiego, Instytutu Slawistyki PAN w Warszawie.

\section{Kilka zdań o wybranych monografiach i artykułach}

Początki były skromne. W artykule Problematyka $i$ stan badań onomastycznych $w$ regionie białostockim jego autor Michał Kondratiuk [1986], którego można nazwać prekursorem badań onomastycznych regionu Podlasie, napisał, że antroponimia tego obszaru w porównaniu z innymi działami onomastyki jest najmniej opracowana, zarówno jeśli chodzi o zbieranie, gromadzenie i udostępnianie materiałów, jak też o ich analizę naukową. Od tego czasu minęło ponad trzydzieści lat. W tym stosunkowo niedługim okresie prowadzono systematyczne i dość intensywne prace. W rezultacie ukazała się ogromna liczba różnorodnych publikacji.

Największe sukcesy należy odnotować w zakresie antroponimii, zwłaszcza jej historycznej części, pomimo że prace badawcze wymagały, m.in. żmudnej kwerendy archiwalnej. Dominuja publikacje dotyczące nazw historycznych, czyli imion i antroponimów, które na przestrzeni stuleci stopniowo przybierały cechy i funkcję współczesnych nazwisk. Ukazało się sporo opracowań monograficznych i bardzo dużo artykułów o charakterze analityczno-syntetycznym, uwzględniających okres XVI-XVIII w. Warto trochę dokładniej scharakteryzować pierwsze prace (zakres tematyczny, chronologiczny, terytorialny), prezentujące początki badań antroponimicznych.

Jedną z tych monografii poświęconych opisowi nazw osobowych jest rozprawa Bazylego Tichoniuka (badacz pochodzący z Podlasia) Antroponimia południowej Białostocczyzny w XVI wieku (1986); nazwa Białostocczyzna ma charakter umowny, bo w tym stuleciu taka nazwa jeszcze nie funkcjonowała. Autor dokonał analizy używanych na badanym terenie różnorodnych form imion, w tym licznych form derywowanych, określił ich frekwencję oraz sposoby przejmowania przez języki słowiańskie (polski, białoruski, ukraiński) zwracając uwagę na różnice formalne, wynikające z różnego pośrednictwa (łacina, język starocerkiewnosłowiański) w procesie ich zapożyczania. Druga zasadnicza część monografii zawiera semantyczno-strukturalną analizę towarzyszących imionom dodatkowych elementów identyfikacyjnych, czyli przezwisk, patronimów, etnonimów, nazw odmiejscowych, herbowych i rodowych.

Szesnastowieczna antroponimia północnych ziem Podlasia, w identycznym niemal zakresie jak antroponimia części południowej tego regionu, zo- 
stała przedstawiona w monografii Lilii Citko zatytułowanej Nazewnictwo osobowe pótnocnego Podlasia w XVI w. [2001]. Autorka zwróciła też uwagę na komponent bałtycki w zasobie nazewnictwa słowiańskiego funkcjonującego w tej części badanego regionu.

Proces kształtowania się nazwisk kobiet na południowym Podlasiu został wszechstronnie scharakteryzowany i udokumentowany w rozprawie Leonardy Dacewicz Nazewnictwo kobiet $w$ dawnym powiecie mielnickim (XVI-XVII w.) [1994]. System nazewnictwa kobiet scharakteryzowano na tle polskiego modelu nazewnictwa męskiego oraz wschodniosłowiańskich struktur identyfikacyjnych identyfikujących kobiety. Zastosowanie metody socjolingwistycznej pozwoliło na uchwycenie prawidłowości funkcjonowania badanych antroponimów w poszczególnych warstwach społecznych.

Elżbieta Bogdanowicz w rozprawie doktorskiej pt. XVIII-wieczne nazewnictwo osobowe południowej Białostocczyzny [Białystok 2000, wydruk komputerowy] dokonała semantyczno-strukturalnej klasyfikacji ponad dwóch tysięcy nazwisk zwyczajowych, funkcjonujących na przestrzeni XVIII w. w południowej części Podlasia, określiła frekwencję typów słowotwórczych, wskazała cechy i kierunki procesów nazwiskotwórczych w ujęciu kulturowym. Analiza została dokonana na bazie rzetelnie opracowanego etymologiczno-motywacyjnego słownika antroponimów.

Z kolei rozprawa doktorska Anny Berlińskiej Antroponimia Tykocina od XVI do XIX wieku [1988, maszynopis] jest warta uwagi ze względu na rzetelnie opracowany słownik antroponimów zawierający dokumentację źródłową aż do XIX w., co pozwoliło dokonać analizy procesów nazwiskotwórczych na przestrzeni czterech stuleci.

W latach 1997-1998 ukazała się praca o charakterze materiałowym, Stownik historycznych nazw osobowych Białostocczyzny (XV-XVII w.), opracowany przez Z. Abramowicz, L. Citko, L. Dacewicz (red. L. Dacewicz). Słownik zawiera materiał źródłowy wyekscerpowany z około czterdziestu dokumentów rękopiśmiennych i drukowanych (część z nich zawiera obfity materiał antroponimiczny) oraz propozycje motywacyjno-etymologiczne prezentowanych antroponimów. Stanowi rzetelną bazę dla realizacji prac monograficznych i artykułów z zakresu historycznej antroponimii Podlasia.

Badaniem historycznego zasobu imion używanych przez mieszkańców Białegostoku zajmowała się Zofia Abramowicz. W monografii Imiona chrzestne białostoczan w aspekcie socjolingwistycznym (lata 1885-1985) [1993], posługując się metodą dokumentacyjno-statystyczną, autorka ustaliła zasób oraz frekwencję imion używanych przez wieloetniczną społeczność Białegostoku na przestrzeni 100 lat. Ponadto badaczka jest autorką dość licznych artykułów na temat imion białostoczan używanych u schyłku XIX 
i w wieku XX. Jeśli chodzi o imiennictwo XIX w. warto przy okazji dodać, że swoistą kontynuacją jest praca L. Dacewicz pt. Uwarunkowania socjologiczno-kulturowe nadawania imion podwójnych w Dekanacie Biatystok w II połowie XIX wieku („Studia Wschodniosłowiańskie”, t. 17, s. 169-186). Zjawisko dwuimienności (wieloimienności) odzwierciedlonej w księgach metrykalnych chrztów kościoła rzymskokatolickiego dekanatu białostockiego z II połowy XIX wieku w takim zakresie (na miarę objętości artykułu) właściwie jest prezentowane po raz pierwszy, nie licząc skromnych, jeśli chodzi o zasięg terytorialny, ale ważnych merytorycznie rozważań dotyczących imiennictwa tylko parafii białostockiej z końca XIX w. autorstwa Z. Abramowicz. Należy mówić głównie o dwuimienności, bowiem na badanym terenie więcej niż dwa imiona nadawano sporadycznie. Przedmiotem uwagi przede wszystkim była skala tego zjawiska w badanym okresie, dziedziczenie imion w rodzinie, motywacja patriotyczna oraz określenie skutków wpływów rosyjskich, które doprowadziły do niemal całkowitego wyeliminowania zwyczaju nadawania imion podwójnych w kościele katolickim na obszarze dekanatu białostockiego.

Liczba kolejnych, nie omówionych tu publikacji, jest imponująca, zwłaszcza artykułów - zob. Załączniki. Ukazały się m.in. monografie i liczne artykuły poświęcone nazewnictwu mniejszości narodowych, które osiedliły się na Podlasiu, tatarskiej, żydowskiej, niemieckiej, a także osiedlonych tu od dawna Litwinów. Antroponimia mniejszości żydowskiej, jako główny przedmiot badań, jest przedstawiona w monografii Z. Abramowicz Nazwiska Żydów białostockich (2010) opartej na rzetelnie opracowanym i wydanym w 2003 r. Stowniku etymologicznym nazwisk Żydów białostockich autorstwa tejże badaczki. Historyczne nazewnictwo żydowskie z wcześniejszego okresu zostało scharakteryzowane w monografii L. Dacewicz, Antroponimia Żydów Podlasia w XVI-XVIII wieku (2008). W kręgu zainteresowań badawczych L. Dacewicz znalazła się także mniejszość tatarska na Podlasiu, czego wyrazem jest monografia Antroponimia Tatarów litewsko-polskich w przekroju historycznym (2012).

W licznych artykułach M. Kondratiuk prezentuje wyniki badań nad bałtyckim komponentem językowym w nazewnictwie osobowym i geograficznym Podlasia. Ujawnia nazwy o genezie litewskiej, opisuje funkcje genetycznie litewskich formantów w słowiańskich onimach, analizuje zjawisko adaptacji bałtyzmów do słowiańskiego systemu językowego (np. Nazwiska pochodzenia battyckiego w regionie białostockim, cz. I: A-J [2000]). Antroponimiczne bałtyzmy stanowiły także przedmiot zainteresowania L. Citko.

Na oddzielną uwage zasługuje wydana w 2017 r. monografia a zarazem edycja źródeł zatytułowana Księi metrykalne chrztów kościoła rzymskoka- 
tolickiego dekanatu białostockiego w II połowy XIX wieku. Treść i struktura metryk. Alfabetyczne spisy imienne, Cz. 1. Rok 1875 autorstwa Leonardy Dacewicz, Jolanty Chomko i Joanny Smakulskiej. W niniejszym tomie przedmiotem uwagi była charakterystyka zespołu archiwalnego, który stanowią księgi metrykalne dekanatu białostockiego z lat 1865-1917 (okres zaboru rosyjskiego), pod kątem ich wartości i przydatności do badań, przede wszystkim historycznych i onomastycznych, przedstawienie historii ksiąg metrykalnych, opis zawartości i struktury ksiąg chrztów oraz alfabetycznych imiennych rejestrów urodzonych, charakterystyka sposobów zapisu polskich własnych nazw osobowych w języku rosyjskim (imion i nazwisk). Jednakże podstawowym celem była edycja oryginalnych alfabetycznych imiennych rejestrów urodzonych (i ochrzczonych) w 1875 r. oraz repolonizacja zawartych w tych spisach antroponimów czyli przywrócenie polskiej wersji zrusyfikowanych imion i nazwisk.

Konieczność rozpoczęcia badań antroponimii Podlasia XIX wieku oraz dostępność bazy źródłowej (bogaty zespół ksiąg metrykalnych kościoła rzymskokatolickiego) zaowocowały publikacją sześciu artykułów uwzględniających głównie antroponimię dekanatu białostockiego w II połowie XIX w. [Zob. np. Dacewicz 2015, 2016, 2017]. Antroponimia tego okresu stanowi także tematykę prac magisterskich realizowanych w Instytucie Filologii Wschodniosłowiańskiej. Badanie antroponimii pierwszej połowy tegoż stulecia wymaga kwerendy w archiwach zagranicznych, głównie w Archiwum Historycznym Litwy w Wilnie.

Nazwiska historyczne oraz współcześnie używane w różnych miejscowościach województwa podlaskiego (ich motywacja znaczeniowa, struktura, frekwencja, formy oficjalne i gwarowe) doczekały się opracowań w postaci prac magisterskich i licencjackich autorstwa studentów Instytutu Filologii Wschodniosłowiańskiej. Zostały napisane pod kierunkiem Z. Abramowicz, E. Bogdanowicz, L. Citko, L. Dacewicz, M. Kondratiuka.

M. Kondratiuk przez wiele lat gromadził (z udziałem studentów-magistrantów) materiały do opracowania słownika współczesnych nazwisk mieszkańców Białostocczyzny i ich form gwarowych (Zob. artykuł M. Kondratiuka, Zasady opracowania i struktura „Stownika współczesnych nazwisk mieszkańców regionu białostockiego").

Dzięki M. Sajewiczowi skromnie reprezentowana antroponimia współczesnego Podlasia wzbogaciła się o obszerną cenną monografię pt. Nazwiska patronimiczne z formantem -uk $w$ powiecie hajnowskim na Białostocczyźnie na tle ogólnopolskim (Lublin 2013). O roli i funkcjach współczesnych nazwisk w nagłówkach prasowych pisała L. Dacewicz (On the Use of Surnames in Polish Newspaper Headlines [2016]). Z kolei E. Bogdanowicz jest 
autorką monografii Konotacje nazw własnych (na materiale publicystyki prasowej) [2017].

Niewiele uwagi poświęcono funkcjonującym na Podlasiu współczesnym przezwiskom i przydomkom. Wynika to m.in. z trudności związanych z dość uciążliwą eksploracją terenową w celu zebrania materiału badawczego. Opublikowano zaledwie kilka artykułów (m.in. prace L. Dacewicz, Z. Abramowicz, M. Mordania). Sprawą nadrzędną wydaje się być zbieranie i gromadzenie przezwisk i przydomków, ponieważ jest to kategoria zmienna i nietrwała, ale cenna dla badań socjologiczno-językowych i dialektologicznych. W niewielkim stopniu zadania te realizuja magistranci z Wydziału Filologicznego UwB.

\section{Toponimia i mikrotoponimia}

Wymienione dyscypliny od dawna znajdowały się w centrum zainteresowań Michała Kondratiuka. Przede wszystkim należy wymienić dwie dobrze znane, nie tylko w kręgach onomastów, monografie: Nazwy miejscowe potudniowo-wschodniej Białostocczyzny (1974), Elementy battyckie w toponimii i mikrotoponimii regionu białostockiego (1985). Problematykę topoonomastyczną badacz prezentował także w wielu artykułach. W swych badaniach wyodrębnił nazwy polskie, białoruskie, ukraińskie, ale też genetyczne lituanizmy o bardzo różnym stopniu i formach slawizacji oraz wiele zapisów gwarowych będących produktem procesu interferencji językowej. Nazwy terenowe wycinkowo były przedmiotem uwagi w artykułach autorstwa Z. Abramowicz, L. Citko, L. Dacewicz, Aliny Filinowicz.

Niewielkim zainteresowaniem cieszyło się nazewnictwo miejskie. Kilka artykułów na ten temat opublikował Jan Nosowicz (wieloletni pracownik Wydziału Filologicznego UwB). Zmianami nazw ulic zajmowały się L. Dacewicz i Z. Abramowicz. Na przykładzie miast Ełk, Gołdap, Olecko (np. Changes in Urbanonymy of Northeastern Poland in the Context of Statehood Transformation [2010]) pokazały polityczne uwarunkowania i charakter zmian w urbanonimii wymienionych aglomeracji. Ponadto nazwy ulic wybranych miejscowości byłego województwa białostockiego stanowiły przedmiot badań magistrantów Wydziału Filologicznego.

Symbolicznie jest reprezentowana najmłodsza dyscyplina onimiczna - chrematonimia. Autorkami kilku artykułów poświęconych nazewnictwu chrematonimicznemu są Z. Abramowicz i L. Dacewicz. Zaledwie kilka artykułów uwzględnia tematykę etnonimiczną. Ich autorką jest L. Dacewicz, np. Etnonimy w stownikach ogólnych języka polskiego i rosyjskiego (Slavia 
Orientalis, t. LXV). Badania z zakresu tej dyscypliny onomastycznej zdecydowanie wychodzą poza obszar Podlasia.

Wyniki badań prezentowano na kongresach i konferencjach naukowych nie tylko w Polsce, także za granicą: na uczelniach i w placówkach naukowych Białorusi, Litwy, Ukrainy, w Barcelonie, Bernie, Bratysławie, Budapeszcie, Helsinkach, Ostravie, Pizie, Pradze, Prešovie, Rydze, Uppsali i innych miastach (zob. Załączniki - wybór publikacji).

Od 1999 r. zaczęła ukazywać się seria wydawnicza „Studia Slawistyczne", dwa pierwsze numery były całkowicie poświęcone problematyce onomastycznej, kolejne-zagadnieniom literackim, kulturowym, językowym, w tym onomastycznym.

\section{Zadania i potrzeby badawcze}

Opublikowane już słowniki, monografie i artykuły nie wyczerpują potrzeb. Zdecydowanie więcej jest do zrobienia niż wskazują na to dotychczasowe dokonania. Zadaniem priorytetowym w zakresie antroponimii Podlasia powinny stać się prace monograficzne obejmujące nazewnictwo nie uwzględnionych jeszcze $\mathrm{w}$ badaniach wybranych miejscowości, powiatów i ziem. Szczególnej uwagi wymaga antroponimia XIX wieku, która jak dotąd nie cieszyła się większym zainteresowaniem badaczy-onomastów. Prace monograficzne, obejmujące całość nazewnictwa osobowego Podlasia, zarówno historycznego, jak i współczesnego, pozwolą opracować słowniki nazwisk mieszkańców tego regionu. Granice chronologiczne pracy mogą wyznaczać ważne wydarzenia historyczne, które prowadziły do zmian politycznych i społecznych, rzutujących na kształtowanie się nazewnictwa i różnego rodzaju procesy nazwotwórcze (np. okres zaborów). Z zagadnień toponomastycznych na opracowanie oczekują mikrotoponimy i urbanonimy. Ważnym zadaniem badawczym w zakresie onomastyki na Podlasiu powinny być prace regionalne dotyczące nazw istniejących $\mathrm{w}$ tym regionie obiektów i instytucji związanych z nowoczesną cywilizacją, czyli chrematonimów.

\section{Podsumowanie}

Liczne prace badaczy onomastów z Wydziału Filologicznego UwB upowszechniły w literaturze przedmiotu problematykę nazewnictwa polsko-litewsko-wschodniosłowiańskiego pogranicza, wzbogaciły wiedzę na temat specyfiki onomastyki wschodniego pogranicza Polski, która kształtowała 
się w sytuacji kontaktu dwóch kultur: wschodnio- i zachodniosłowiańskiej, a w konsekwencji dwóch systemów wartości, czego wyraźne dowody znajdujemy w antroponimii i toponimii.

W oparciu o konkretne fakty onomastyczne badacze podejmowali zagadnienia natury teoretycznej, a mianowicie problem obcości i rodzimości nazw na pograniczach etniczno-językowych, problem miejsca i roli nieoficjalnych systemów nazewniczych, klasyfikacji nazwisk, interdyscyplinarności badań onomastycznych (zob. artykuły L. Dacewicz: Obce czy rodzime? $W$ kwestii nazewnictwa na polsko-wschodniostowiańskim pograniczu, Lokalny antroponimiczny mikrosystem nazewniczy, Interdyscyplinarny charakter badań onomastycznych). Teoretyczno-metodologiczne propozycje badawcze zawierają prace dotyczące polskiej terminologii onomastycznej (Z. Abramowicz, L. Dacewicz „Onomastica” 1995), miejsca i roli onomastyki w świadomości i edukacji mieszkańców regionu (potrzeba włączenia pewnego zakresu wiedzy onomastycznej do programów nauczania uniwersytetów i szkół, L. Dacewicz).

Regionalne badania onomastyczne lączac metody badawcze stosowane $\mathrm{w}$ językoznawstwie synchronicznym z metodologią badawczą językoznawstwa diachronicznego. Wymagają wszechstronnego wykorzystania źródeł historycznych, współpracy językoznawców-onomastów z historykami, zwłaszcza tymi, którzy zajmują się historią osadnictwa na danym terenie. Każda regionalna monografia onomastyczna wymaga doskonałej znajomości historii politycznej, społecznej i osadniczej badanego terenu oraz języków i dialektów żyjących tam ludzi. Nazwy należy badać jako przejaw działalności człowieka w konkretnym czasie i w określonym miejscu, w ich wzajemnym powiązaniu i zależnościach. Badania antroponimiczne dodatkowo wymagają znajomości toponimii regionu, a badania toponomastyczne - antroponimii regionu. Dotychczasowy dorobek badaczy onomastów z Wydziału Filologicznego UwB, dotyczący Podlasia, stanowi poważny wkład do rozwoju onomastyki słowiańskiej, ma ogromną wartość dla badaczy historii i kultury tego wieloetnicznego i wielowyznaniowego regionu pogranicza. Trzeba w tym miejscu zaznaczyć, że omawiane tu badania onomastyczne cechuje regionalizm ujmowany w kontekście ogólnopolskim, a nawet szerzej - słowiańskim, i to jest ich wartość podstawowa.

\section{Literatura}

Dacewicz L., 2003, Zakres i kierunki badań onomastycznych na Białostocczyźnie, (w:) Metodologia badań onomastycznych, red. M. Biolik, Olsztyn, s. 91-98. 
Dacewicz L., 2015, Rusyfikacja nazewnictwa osobowego w katolickich ksiegach metrykalnych dekanatu białostockiego w okresie zaboru (lata 1865-1918), „Slavia Orientalis", t. LXIV, nr 2, Warszawa, s. 363-374.

Dacewicz L. 2016, Struktura i treść notacji metrykalnych kościoła rzymskokatolickiego w okresie zaboru rosyjskiego w diecezji wileńskiej, „Studia Wschodniosłowiańskie", t. 16 , s. 365-384.

Dacewicz L., 2016, Ksiegi metrykalne dekanatu Białystok, Grodno i Sokótka z drugiej polowy XIX w. jako źródła do historii spoleczeństwa polsko-wschodniosłowiańskiego pogranicza, (w:) Archiwalne dziedzictwo, pod red. ks. A. Szota, Seria Białostockie Studia Historyczno-Kościelne, t. XVIII, Białystok 2016, s. $77-89$.

Dacewicz L., 2017, Elementy obcości w nazewnictwie osobowym pótnocno-wschodnich kresów Rzeczpospolitej w okresie zaboru rosyjskiego, (w:) Obcy. Inny. Analiza przypadków, red. M. Karwatowska, R. Litwiński, A. Siwiec, Wydawnictwo Uniwersytetu Marii Curie-Skłodowskiej, Lublin, s. 219-230.

Kondratiuk M., 1986, Problematyka $i$ stan badań onomastycznych $w$ regionie biatostockim, „Białostocczyzna” 1.

Liczne publikacje podano w tekście artykułu. Prace w wyborze zawierają też Załączniki.

\author{
THE REGION OF PODLASIE IN ONOMASTIC RESEARCH \\ FROM A HISTORICAL PERSPECTIVE: \\ THE PRESENT STATE, OBJECTIVES AND NEEDS
}

S U M M A R Y

The article discusses the extensive scholarly output of linguists investigating the onomastic inventory of Podlasie region: namely, the onomasticians working at the Faculty of Philology of the University of Bialystok. The abundance and variety of the works published so far make them be a considerable input towards the development of Slavic onomastics and a valuable asset to the study of Polish eastern frontier's history and culture. The publications are indicative of systematically conducted onomastic investigations marked by regionalism presented from an all-Poland, if not a wider, Slavic perspective. This feature seems to be the primary value of the studies in question.

Regional onomastic research combine investigation methods of synchronic and diachronic linguistics. They require comprehensive use of historical sources and a close collaboration between linguists (onomasticians), dialectologists and historians, i.e. an excellent knowledge of political, social and cultural history of the region, as well as of the languages spoken by people who have settled and lived there. 


\section{Załączniki}

\section{PUBLIKACJE (w wyborze)}

\section{MONOGRAFIE}

\section{Zofia Abramowicz}

1. Imiona chrzestne białostoczan $\mathrm{w}$ aspekcie socjolingwistycznym (lata 1885-1985), Białystok 1993, 509 s.

2. Antroponimia Żydów białostockich, Białystok 2010, 490 s.

\section{Leonarda Dacewicz}

1. Nazewnictwo kobiet $\mathrm{w}$ dawnym powiecie mielnickim (XV-XVII w.), Białystok 1994, $294 \mathrm{~s}$.

2. Antroponimia Białegostoku w XVII-XVIII wieku, Białystok 2001, $297 \mathrm{~s}$.

3. Antroponimia Żydów Podlasia w XVI-XVIII wieku, Białystok 2008, $207 \mathrm{~s}$.

4. Antroponimia Tatarów litewsko-polskich w przekroju historycznym, Białystok 2012, $258 \mathrm{~s}$.

5. Historia nazwisk na kresach północno-wschodnich Rzeczpospolitej (XVI-XVIII w.), Białystok 2014, 463 ss.

\section{Lila Citko}

1. Nazewnictwo osobowe północnego Podlasia w XVI w., Białystok 2001.

2. „Kronika Bychowca” na tle historii i geografii języka białoruskiego, Białystok 2006.

\section{Elżbieta Bogdanowicz}

1. Konotacje nazw własnych (na materiale publicystyki prasowej), Białystok 2017.

\section{Michał Kondratiuk}

1. Nazwy miejscowe południowo-wschodniej Białostocczyzny, Białystok 1974.

2. Elementy bałtyckie w toponimii i mikrotoponimii regionu białostockiego, Ossolineum, Wrocław-Warszawa-Kraków 1985, 291 s.

\section{OPRACOWANIA LEKSYKOGRAFICZNE}

1. Z. Abramowicz, L. Citko, L. Dacewicz, Słownik historycznych nazw osobowych Białostocczyzny (XV-XVII w.), pod red. L. Dacewicz, t. I-II, Białystok 1997-1998, 281 i 211 s.

2. Z. Abramowicz, Słownik etymologiczny nazwisk Żydów białostockich, Białystok 2003, 366 s. 
3. L. Dacewicz, Słownik najstarszych nazwisk polskich. Pochodzenie językowe (XII-XV wiek), t. I, Warszawa 2007 - współaut. z Z. Kowalik-Kaletą i B. Raszewską-Żurek, $50 \mathrm{~s}$.

\section{EDYCJA ŹRÓDEE}

1. L. Dacewicz, J. Chomko, J. Smakulska, Księgi metrykalne chrztów kościoła rzymskokatolickiego dekanatu białostockiego w II połowy XIX wieku. Treść i struktura metryk. Alfabetyczne spisy imienne, Cz. 1. Rok 1875, Białystok 2017, 238 s.

\section{ARTYKUEY (wybór)}

\section{Zofia Abramowicz}

1. Anthroponymy of the Jews from Bialystok as a reflection of thr nation's culture and history, „Namenkundliche Informationen”, 79/80, Leipzig 2001.

2. Rola imienia w identyfikacji ludności żydowskiej na Podlasiu w XVIXX wieku, Silva Rerum Philologicarum, Studia ofiarowane Profesor Marii Strycharskiej-Brzezinie z okazji Jej jubileuszu, Kraków 2010, red. nauk. Janusz S. Gruchała i Halina Kurek, s. 33-44.

3. Antroponimia a tożsamość narodowa, (w:) Nazwy własne a społeczeństwo, t. I, Łask 2010, red. nauk. Romana Łobodzińska, s. 129-140.

4. Identyfikacja ludności żydowskiej na ziemiach polskich i białoruskich (XVI-XVIII w.), „Acta Onomastica”, Praha 2011, Ročník LII, s. 7-14.

5. Stereotyp Żyda utrwalony w polskiej i rosyjskiej frazeologii, „Studia Wschodniosłowiańskie", 2011, t. 11, s. 139-149.

6. Stereotype of a Jew in Polish and Russian proverbs and idioms lauhakangas, Outi (red.) Portugalia, Tavira: AIP-IAP, s. 416-425, $4^{\circ}$ Colóquio interdyscyplinarnych sobre Provérbios 4. Interdyscyplinarne Colloquium: Actas ICP10, 2011, red. naukowa SOARES, Rui João Baptista.

7. Nominacja ludności żydowskiej w najstarszych metrykach XIX wieku z regionu Podlasia, „Poradnik Językowy”, 2011, 7 (686), s. 90-106.

8. The Role of the Name in the Identification of Jews in the Podlasie in the $16^{\text {th }}-20^{\text {th }}$ Centuries, Ashkenazim and Sephardinm a European Perspective, Andrzej Kątny/Izabela Olszewska/Aleksandra Twardowska (eds.), Frankfurt am Main: Peter Lang GmbH Internationaler Verlag der Wissenschaften, 2013, s. 175-187, p. 5.

9. Развитие антропонимической системы в еврейско-славянской среде, (w:) „Onomastika spētījumi - Onomastic Investigations", Ryga 2014, s. $213-237$. 
10. Wschodniosłowiańskie formy imion chrzestnych na Podlasiu $\mathrm{w}$ XVIXVII w., (w:) Беларуска-польскія моўныя, літаратурныя, гістарычныя і культурныя сувязі, red. А. M. Mezenko, Мінск 2015, s. 12-26.

11. Imiona starotestamentowe w kulturze podlaskich Żydów i chrześcijan, „Onomastica”, Rocznik LX, 2016, s. 69-89.

\section{Zofia Abramowicz, Leonarda Dacewicz (współaut.)}

1. Changes in Urbanonymy of Northeastern Poland in the Context of Statehood Transformation, „Acta Onomastica”, Ročnik LI, Praha 2010, s. $417-428$.

2. W komunikacji przestrzeni nazw własnych i pospolitych, Proces stabilizacji i przyjmowania nazwiska dziedzicznego przez Żydów Podlasia, Wydawnictwo UŚ, Katowice 2012, red. nauk. I. Łuc, M. Pogłódek, s. $31-42$.

3. Polityczne aspekty przemian w nazewnictwie miejskim Polski północno-wschodniej w przekroju historycznym, „Studia Wschodniosłowiańskie", 2012, t. 12, s. 187-198.

4. The development of Jewish anthroponymic system in north-eastern Poland - the historical perspective, (w:) DOI: 10.2436/15.8040.01.70; WW11 Els noms en la vida quotidiana. Actes del XXIV Congres Internacional d'ICOS sobre Ciencies Onomastiques. - Barcelona, p. 668-677, Barcelona 2014.

\section{Leonarda Dacewicz}

1. Nazewnictwo osobowe regionu białostockiego w ujęciu historycznym, „Onomastica” XLI, 1996, s. 73-81.

2. The different ethnic cultures in the anthtoponymic system of North-eastern Poland, (w:) Ot slova k tekstu, Minsk 2000.

3. The anthroponymy of Bialystok during Prussian Administration, „Namenkundliche Informationen", Heft 1978/80, Leipzig 2001.

4. Z historii antroponimii polsko-wschodniosłowiańskiego pogranicza kulturowego, (w:) Nazwy własne a kultura. Polska i inne kraje słowiańskie, Warszawa 2003, s. 11-19.

5. Identifizierung der jüdischen Bevölkerung und slavische Eigennamenkultur in der alten Wojewodschaft von Podlasie, (w:) Namenkundliche Informationen, Heft 85/86, Leipzig 2004;

6. The anthroponymic system in the Polish and eastern Slavic borderland compared to the ethnic structure, (w:) Proceedings of the 21st International Congress of Onomastic Sciencies, t. 3, Uppsala 2007, p. 89-97. 
7. Paralelne formy nazwisk polskich i wschodniosłowiańskich świadectwem historycznych kontaktów wschodnio- i zachodniosłowiańskich, (w:) Súradnice súčasnej onomastyki, red. M. Považaj i P. ` Zigo, Bratysława 2007, s. 132-138.

8. Nazwiska ludności chrześcijańskiej i żydowskiej dawnej Polski północno-wschodniej, „Acta Onomastica”, R. IL, Praha 2008.

9. Nazewnictwo niesłowiańskich mniejszości narodowych Polski północno-wschodniej w kontekście polskiej i wschodniosłowiańskiej kultury nazewniczej, (w:) Mnohotvarnost a specifičnost onomastyki, Ostrava-Praha 2010 , s. $120-131$.

10. Changes in Urbanonymy of Northeastern Poland in the Context of Statehood Transformation, „Acta Onomastica”, Rocnik LI, 2, Praha 2010, s. $417-128$.

11. Из проблематики сопоставительного анализа словообразовательных типов русских и польских этнонимов, „Acta Albaruthenica, Rossica, Polonica", Witebsk 2013, s. 212-216.

12. Названия британских, польских и русских высших учебных заведений с отождествляющим элементом универсuтem, (w:) Onomastikas pētījumi - Onomastic Investigations, Ed. Ojãrs Bušs, Lu Latviešu valodas institūtis (Latvian Language Institute), University of Latvia, Ryga 2014, s. $362-377$.

13. Rusyfikacja nazewnictwa osobowego w katolickich księgach metrykalnych Dekanatu białostockiego w okresie zaboru (lata 1865-1918), „Slavia Orientalis", t. LXIV, nr 2, Warszawa 2015, Wyd. Komitet Słowianoznawstwa PAN, s. 363-374.

14. On the Use of Surnames in Polish Newspaper Headlines, „Acta Onomastica", R. LVI, Praha 2016, s. 62-75.

15. Etnonimy w słownikach ogólnych języka polskiego i rosyjskiego, „Slavia Orientalis", R. LXV, nr 2, Warszawa 2016, s. 363-376.

16. Struktura i treść notacji metrykalnych kościoła rzymskokatolickiego w okresie zaboru rosyjskiego w diecezji wileńskiej, „Studia Wschodniosłowiańskie", t. 16, Białystok 2016.

\section{Michał Kondratiuk}

1. Problemy badania wpływów gwar litewskich na słowiańską antroponimię regionu białostockiego, (w:) Letuvių kalbotyros klausimai XXX. Periferines letuviu kalbos tarmes, Vilnius 1993, s. 74-81.

2. Formant -uć (lit. -utis) w nazwach geograficznych i osobowych na terenie Białostocczyzny, (w:) Проблеми сучасноі ареалогіi, Киів 1994, c. $159-166$. 
3. Nazwiska pochodzenia bałtyckiego w regionie białostockim, cz. I: A-J, „Acta Baltico-Slavica", 2000, t. XXV, s. 123-150.

4. Toponimia i mikrotoponimia jako źródło w badaniach przeszłości etnicznej i językowej regionu białostockiego, (w:) Надзенныя пытанни лингвистыки (да 75-годдзя прафесара П.У. Сцяцко), Гродна 2005, c. 205-209.

5. Zasady opracowania i struktura „Słownika współczesnych nazwisk mieszkańców regionu białostockiego", (w:) Onimizacja i apelatywizacja, pod red. Z. Abramowicz i E. Bogdanowicz, Białystok 2006, s. 405-413.

\section{Lila Citko}

1. Elementy wschodniosłowiańskie w szesnastowiecznej antroponimii północnej Białostocczyzny, (w:) Ze studiów nad gwarami wschodniosłowiańskimi w Polsce, pod red. F. Czyżewskiego, Lublin 1997, s. 239-245.

2. Odetniczne nazwy osobowe na Podlasiu (XVI-XVII w.), „Studia Russica", XVIII, pod red. A. Zoltana, Budapeszt 2000, s. 39-44.

3. O pewnej słowiańsko-bałtyckiej paraleli semantycznej w mikrotoponimii Podlasia, „Acta Onomastica”, LIV, 2013, s. 43-52.

4. Akty Horodelskie z 1413 r. jako źródło do historii antroponimii polskiej i litewsko-ruskiej, „Studia Wschodniosłowiańskie”, t. 15, 2015, s. 209-218.

5. Toponimia Narwiańskiego Parku Narodowego i okolic, (w:) Narwiański Park Narodowy. Krajobraz, przyroda, człowiek, pod red. P. Banaszuka i D. Wołkowyckiego, Białystok-Kurowo 2016, s. 305-310.

\section{Elżbieta Bogdanowicz}

1. Proces kształtowania się nazewnictwa osobowego południowej Białostocczyzny, (w:) Nazwy własne na pograniczach kulturowych, Studia Slawistyczne 2, Białystok 2000, s. 21-28.

2. Sposoby nominacji kobiet w XVIII-wiecznej antroponimii południowej Białostocczyzny, „Studia Wschodniosłowiańskie”, t. 3, Białystok 2003, s. $167-176$.

3. Polskie i wschodniosłowiańskie tradycje nazewnicze w XVIII-wiecznej antroponimii południowej Białostocczyzny, (w:) Ze studiów nad językami i literaturami wschodniosłowiańskimi, red. B. Tichoniuk, W. Wilczyński, Zielona Góra 2004, s. 117-122.

4. Nazwiska z komponentem -k- w części sufiksalnej na podstawie XVIII-wiecznych ksiąg metrykalnych południowej Białostocczyzny, (w:) Onimizacja i apelatywizacja, red. Z. Abramowicz, E. Bogdanowicz, Białystok 2006, s. 337-343. 
5. O roli czynnika emocjonalnego $\mathrm{w}$ procesie kreacji nazw osobowych, „Studia Wschodniosłowiańskie”, t. 6, Białystok 2006, s. 189-195.

6. Wyrazy pospolite motywowane nazwami własnymi (na przykładach polskich i rosyjskich), (w:) Słowotwórstwo i tekst, Prace Slawistyczne 124, red. V. Maldjieva, Z. Rudnik-Karwatowa, Warszawa 2007, s. 29-36.

7. Nazwy osobowe w metaforach (na współczesnym materiale prasowym), (w:) Nowe nazwy własne - nowe tendencje badawcze, red. A. Cieślikowa, B. Czopek-Kopciuch, K. Skowronek, Kraków 2007, s. 281-286.

8. Najnowsze derywaty odnazewnicze (na materiale prasowym), (w:) Mnohotvárnost a specifičnost' onomastyky. IV. česká onomastická konference, Ostrava 2010, s. 73-81.

9. Konotacje wartościujące nazw własnych, (w:) Nazwy własne a społeczeństwo, t. I, I. Zagadnienia teoretyczne i metodologiczne, II. Antroponimia, red. R. Łobodzińska, Wyd. Uniwersytetu Wrocławskiego, Łask 2010, s. $115-126$.

10. O pojęciu konotacji $\mathrm{w}$ lingwistyce (na przykładach polskich i rosyjskich), „Studia Wschodniosłowiańskie”, t. 13, Białystok 2013, s. 7-17.

11. Nazwy własne a semantyka, (w:) Leksyka języków słowiańskich w badaniach synchronicznych i diachronicznych, red. M. Gębka-Wolak, J. Kamper-Warejko, A. Mróz, Toruń 2014, s. 15-28.

12. Wartości konotacyjne wybranych toponimów (na materiale publicystyki prasowej), (w:) Mikrotoponimy i makrotoponimy w komunikacji i literaturze, red. A. Gałkowski, R. Gliwa, Łódź 2015, s. 307-317.

13. Nazwy własne w funkcji metaforycznej (na polskich i rosyjskich przykładach prasowych), „Studia Wschodniosłowiańskie”, t. 15, Białystok 2015, s. $187-196$.

14. Rola nazw własnych w publicystycznych tekstach prasowych, „Prace Językoznawcze", t. XVIII, z. 3, Olsztyn 2016, s. 7-17.

\section{Serie wydawnicze poświęcone badaniom językoznawczym, w tym onomastycznym, „Studia Slawistyczne", "Chrześcijańskie dziedzictwo duchowe narodów słowiańskich" (w wyborze)}

1. Studia Slawistyczne nr 1: Nazewnictwo na pograniczach etniczno-językowych, red. nauk. Zofia Abramowicz, Leonarda Dacewicz, Białystok 1999, $349 \mathrm{~s}$.

2. Studia Slawistyczne nr 2: Nazwy własne na pograniczach kulturowych, red. nauk. Zofia Abramowicz, Leonarda Dacewicz, Białystok 2000, $302 \mathrm{~s}$. 
3. Studia Slawistyczne nr 3: Wielojęzyczność i wielokulturowość na pograniczu polsko-wschodniosłowiańskim, red. nauk. Zofia Abramowicz, Białystok 2002, $248 \mathrm{~s}$.

4. Studia Slawistyczne nr 4: Wielojęzyczność i wielokulturowość pogranicza w kontekście nauczania języków obcych, red. nauk. Zofia Abramowicz, Białystok 2003, $130 \mathrm{~s}$.

5. Chrześcijańskie dziedzictwo duchowe narodów słowiańskich, seria wydawnicza poświęcona badaniom literackim, językoznawczym, kulturoznawczym i historycznym, 2003, Wydawnictwo Uniwersytetu w Białymstoku, red. nauk. Zofia Abramowicz, Białystok 2005, 677 s.

6. Studia Slawistyczne nr 6: Język i kultura mniejszości narodowych w dobie globalizacji, seria wydawnicza poświęcona badaniom językoznawczym i kulturoznawczym, red. nauk. Zofia Abramowicz, Białystok 2005, $253 \mathrm{~s}$.

7. Onimizacja i apelatywizacja, praca zbiorowa poświęcona badaniom onomastycznym, 2006, red. naukowa Zofia Abramowicz i Elżbieta Bogdanowicz, Białystok 2006, 655 s.

8. Chrześcijańskie dziedzictwo duchowe narodów słowiańskich. Wokół kultur śródziemnomorskich, seria wydawnicza poświęcona badaniom literackim, językoznawczym, kulturoznawczym i historycznym, red. nauk. Zofia Abramowicz, Jarosław Ławski, tom I-II, Białystok 2009, 694 s.

9. Chrześcijańskie dziedzictwo duchowe narodów słowiańskich. Wokół kultur śródziemnomorskich, red. nauk. Zofia Abramowicz, Jarosław Ławski, Białystok 2010, I-II, $563 \mathrm{~s}$.

III. Czasopismo „Studia Wschodniosłowiańskie”, t. 1-17, Białystok 2000-2017, Wyd. UwB (10 pkt) - m.in. zamieszcza artykuły z zakresu onomastyki 